\title{
Meta-Analysis of Randomized Trials on First Line and Adjunctive Levetiracetam
}

\author{
Benjamin W. Y. Lo, Hmwe H. Kyu, Draga Jichici, Adrian M. Upton, Elie A. Akl, \\ Maureen O. Meade
}

\begin{abstract}
Context: New evidence suggests that levetiracetam may be as effective as traditional agents, with better safety profile. Objective: To synthesize evidence regarding efficacy and tolerability of levetiracetam as first line, adjunctive or prophylactic antiepileptic agent. Study Selection \& Data Extraction: Eligible studies were randomized controlled trials (RCTs) of levetiracetam used in adults with epilepsy. MEDLINE, EMBASE, CENTRAL, CINHAL, PAPERSFIRST, PROCEEDINGSFIRST, PROQUEST and conference proceedings identified studies (to September 30, 2010). Two investigators independently selected, appraised studies, collected and analyzed data. Results: Of ten eligible randomized trials, eight investigated adjunctive levetiracetam for refractory seizures, one as monotherapy for newly diagnosed seizures, one as monotherapy for prophylaxis. Eight RCTs of adjunctive levetiracetam were of moderate quality (GRADE criteria), with two showing lack of allocation concealment. Meta-analyses showed adjunctive levetiracetam was more effective than placebo in achieving at least $50 \%$ reduction of seizure frequency, when added to baseline antiepileptic regimen (pooled RR $2.15[1.65,2.82], \mathrm{I}^{2}=45 \%, \mathrm{p}$ value (heterogeneity) $=0.08, \mathrm{p}$ value (overall effect) $<0.01$ ). Likelihood of serious adverse events necessitating withdrawal from study was not significantly different between levetiracetam and control (pooled RR $1.37[0.88,2.13], \mathrm{I}^{2}=0 \%, \mathrm{p}$ value (heterogeneity) $=0.84, \mathrm{p}$ value (overall effect) $=0.17$ ). Subgroup analyses suggested similar effects across different dosages. Sensitivity analysis of studies with adequate concealment showed similar effects. Conclusions: Levetiracetam is an effective adjunctive agent for refractory epilepsy. More studies are needed to establish whether it is effective as monotherapy for newly diagnosed seizures, and for prophylaxis in traumatic brain injury.
\end{abstract}

RÉSUMÉ: Méta-analyse d'essais randomisés évaluant le lévétiracétam comme traitement de première intention ou d'appoint. Contexte : Selon des données récentes, le lévétiracétam serait aussi efficace que les agents traditionnels et bénéficierait d'un meilleur profil de sécurité. Objectif : Le but de cette étude était de faire la synthèse des données concernant l'efficacité et la tolérance du lévétiracétam comme traitement de première intention, comme médicament d'appoint ou comme agent antiépileptique prophylactique. Choix des études et recueil des données : Nous avons choisi les essais cliniques contrôlés randomisés évaluant le lévétiracétam chez des adultes épileptiques ainsi que les comptes rendus de conférences, publiés avant le 30 septembre 2010 dans les bases de données MEDLINE, EMBASE, CENTRAL, CINHAL, PAPERSFIRST, PROCEEDINGSFIRST et PROQUEST. Deux chercheurs ont choisi les essais cliniques de façon indépendante, les ont évalués et ont colligé et analysé les données. Résultats : Parmi les 10 essais cliniques randomisés éligibles, 8 portaient sur le lévétiracétam comme médicament d'appoint pour traiter l'épilepsie réfractaire au traitement, 1 comme médicament de première intention chez des patients au moment du diagnostic de l'épilepsie et 1 comme monothérapie en prophylaxie. Huit des essais cliniques randomisés évaluant le lévétiracétam comme médicament d'appoint étaient de qualité moyenne (critères GRADE), dont 2 où le traitement n'était pas en aveugle. Les méta-analyses ont montré que le lévétiracétam comme traitement d'appoint était plus efficace que le placebo pour diminuer d'au moins $50 \%$ la fréquence des crises quand il était ajouté au régime posologique de base (RR global 2,15 [1,65 - 2,82] ; $12=45 \%$, p (hétérogénéité) $=0,08 ; \mathrm{p}$ effet global $<0,01)$. La probabilité que des incidents thérapeutiques sérieux entraînent le retrait du patient de l'étude n'était pas significativement différente entre le groupe recevant le lévétiracétam et le groupe témoin (RR global 1,37 [0,88 - 2,13]; $12=0 \% ; \mathrm{p}$ (hétérogénéité) $=0,84 ; \mathrm{p}$ effet global $=0,17$ ). Selon les analyses de sous-groupes, les effets seraient les mêmes, quelle que soit la posologie. Les analyses de sensibilité des études bien menées à l'insu ont montré des effets similaires. Conclusions : Le lévétiracétam est un médicament d'appoint efficace dans l'épilepsie réfractaire au traitement. Il devra faire l'objet de nouvelles études pour établir son efficacité en monothérapie chez les patients dont le diagnostic est récent et en prophylaxie chez les patients qui ont subi un traumatisme crânien.

Can. J. Neurol. Sci. 2011; 38: 475-486

Levetiracetam, a pyrrolidine, the racemically pure Senantiomer of pyrrolidineacetamide, is an antiepileptic medication with a novel mechanism, related to a specific binding site in the brain for the synaptic vesicle protein $2 \mathrm{~A}^{1}$. In contrast to the mechanism of traditional antiepileptics, there is no evidence for action on voltage-gated sodium channel, gammaamino butyric acid, or glutamate-mediated synaptic transmission $^{2}$. Levetiracetam has a linear pharmacokinetic profile, high oral bioavailability (close to 100\%), and is not bound to proteins, with $95 \%$ being metabolized and excreted in urine $^{3}$. Plasma concentrations peak within one hour, with steady- state concentrations at 48 hours with repeated dosing ${ }^{4}$. Its half life is between six to eight hours, with dosing between 1000$3000 \mathrm{mg}$, with minimal drug-drug interactions ${ }^{4}$. The most

From the Division of Critical Care Medicine, Department of Clinical Edpiemiology \& Biostatistics (BWYL, MOM, HHK, DJ, AMU, EAA), McMaster University, Hamilton; Division of Neurosurgery (BWYL), University of Toronto, Toronto, Ontario, Canada; Department of Medicine (EAA), University of Buffalo, Buffalo, NY, USA.

Received November 4, 2010. Final Revisions Submitted January 17, 2011 Correspondence to: Benjamin W.Y. Lo, Faculty of Health Sciences, McMaster University, Room 2U, 1200 Main Street West, Hamilton, Ontario, L8N 3Z5, Canada. 
common side effects of levetiracetam include somnolence, asthenia and dizziness ${ }^{5}$. Meta-analysis suggests that the extended release version of this medication, when compared to placebo, may be associated with lower incidence of nervous system, psychiatric, nutritional and metabolic adverse effects ${ }^{2-5}$. So far, only four systematic reviews ${ }^{2-5}$ have been conducted verifying its efficacy as a sole agent in refractory partial-onset seizures, as well as adjunctive agent in epilepsy. These studies were limited by lack of clarity in selection criteria, exclusion of potentially relevant trials, lack of critical appraisal of primary studies, and for-profit funding of most trials.

\section{OвJectives}

The purpose of this review and meta-analysis is to systematically collect, critically appraise, and synthesize current evidence regarding the efficacy and tolerability of levetiracetam as a first line or adjunctive agent for adults suffering from idiopathic and secondary epilepsy, or those at risk.

\section{Methods}

We included randomized trials of adult patients (older than 18 years) with EEG-documented epilepsy (including primary or refractory partial, complex partial, or generalized epilepsy, including both idiopathic and secondary seizures), comparing levetiracetam with dosing up to $3000 \mathrm{mg} /$ day, as a single agent or as adjuvant therapy, to no therapy, placebo, or existing regimens (usually dilantin, carbamazepine, or valproic acid). We were interested in the following outcomes, where available:

(1) greater than $50 \%$ reduction in seizures $(\geq 50 \%$ responder), and if available from study,

(2) six-month seizure freedom (proportion of patients remaining seizure free for at least six months), and

(3) any adverse effects.

In these trials, refractory epilepsy has been defined as recurrent seizures despite receiving at least one but no more than three concomitant antiepileptic medications. Eligible studies required a minimum follow-up of one year. We excluded studies including pediatric patients (younger than 18 years), pregnant and/or lactating patients, those with status epilepticus, those without electroencephalogram (EEG) confirmation, including patients with pseudo-seizures, and those with multiple organ dysfunction.

\section{Literature Search}

Two reviewers (BL, HK) independently searched the following electronic databases (to September 30, 2010) with the assistance of a medical librarian: OVID Medline, OVID EMBASE, the Cochrane Central Register of Controlled Trials (CENTRAL), clinicaltrials.gov, and the cumulative Index to Nursing and Allied Health Literature (CINAHL), without language restrictions. To include grey literature, we also searched PROCEEDINGSFIRST, and PAPERSFIRST. Proceedings of the following meetings were also searched: European Association of Neurosurgical Societies Annual Meeting (2003-2009), American Association of Neurological Surgery Annual Meeting (2003-2009), Annual Meeting of the American Epilepsy Society (2003-2009), International Epilepsy
Congress Annual Meeting (2003-2009), American Academy of Neurology Annual Meeting (2003-2009), and the Canadian Neurological Sciences Federation Annual Meeting (2003-2009).

We used the following search terms: levetiracetam, keppra, seizures and epilepsy. Several search strategies were used to maximize the number of citations generated.

\section{Study Selection}

Both investigators reviewed all titles and abstracts, and full reports of all potentially relevant trials. Interrater reliability was very high (Kappa 1.0 for citation and abstract screening). BL and HK independently applied the inclusion criteria to the full reports using the aforementioned study eligibility form. Each trial report was examined carefully for its methodologic quality (kappa statistic $=0.87$ ). Excluded studies are listed, with reason for exclusion in the "Characteristics of excluded studies" table. (Table 1). Disagreements were resolved through discussion and consensus discussions.

\section{Data Collection Process}

Two reviewers (BL, HK) tested a data extraction form and corresponding explanatory manual on three studies, revised as needed, and then used the final version of the form to independently extract data from each of the 16 studies. Disagreements were resolved by consensus discussions.

We recorded patient demographics, study and control interventions, study design, research ethics board approval, informed consent, study locations, author affiliations, method of randomization, presence of allocation concealment, length and frequency of treatments (including dose changes), duration of follow-ups, early stoppage of trials, as well as adverse events reporting. For each outcome, we noted the number of participants randomized and the number analyzed in each treatment group. For dichotomous outcomes, we noted the number of participants experiencing the outcome, and the number assessed in each treatment group. For continuous outcomes, we recorded means, standard deviations or medians, and interquartile ranges for each treatment group, together with the numbers assessed in each group. Disagreements between reviewers were resolved through consensus discussions.

\section{Risk of Bias in Individual Studies}

Both reviewers reviewed for likelihood of bias, including consistency of results, directness of evidence, imprecision and publication bias. In particular, the reviewers noted whether each study used the following methodologic qualities: allocation concealment, intention to treat analysis, adequate blinding, inclusion of all randomized patients in the analysis, completeness of follow-up, early stopping of trial, and selective outcome reporting.

\section{Summary Measures}

The primary outcome of interest to this review was $50 \%$ reduction in seizure frequency. Secondary measures included serious adverse events necessitating withdrawal from study. 


\section{Synthesis of Results}

Data were analyzed with Review Manager 5 (RevMan) using relative risk for dichotomous data. It was used to measure for consistency of each meta-analysis. If there was discrepancy between the number randomized and the number analyzed, we noted the number loss to follow-up for each treatment group and reported this information.

We assessed for statistical heterogeneity by inspecting forest plots for overlapping confidence intervals, applying both the $\mathrm{p}$ value for heterogeneity, $\mathrm{p}$ value for overall effect, and the $\mathrm{I}^{2}$ test $\left(\mathrm{I}^{2}<30 \% \text { : mild, 30-50\%: moderate, }>50 \% \text { : substantial }\right)^{6}$. We pooled data using random effects model. Pre-specified potential sources of heterogeneity included seizure subtypes, drug dosages and formulations, treatment lengths, number of baseline drugs, severity of disease and causes of seizures, route of administration, allocation concealment, blinding and patient ethnicity.

\section{Assessment of Methodological Quality}

Assessment of methodological quality for included studies was performed according to the GRADE criteria, with the addition of a synthesis GRADE Profile Table ${ }^{6-8}$. Assessments included generations of the allocation sequence and concealment classified as adequate, inadequate, or unclear (Juni, Altman, \& Egger, 2001) ${ }^{6}$. In generation of allocation sequence, if the method used was described and the resulting sequences were unpredictable, it was classified as adequate. If the trial was randomized, but the method was not described, it was classified as unclear. If sequences could be predicted, it was classified as

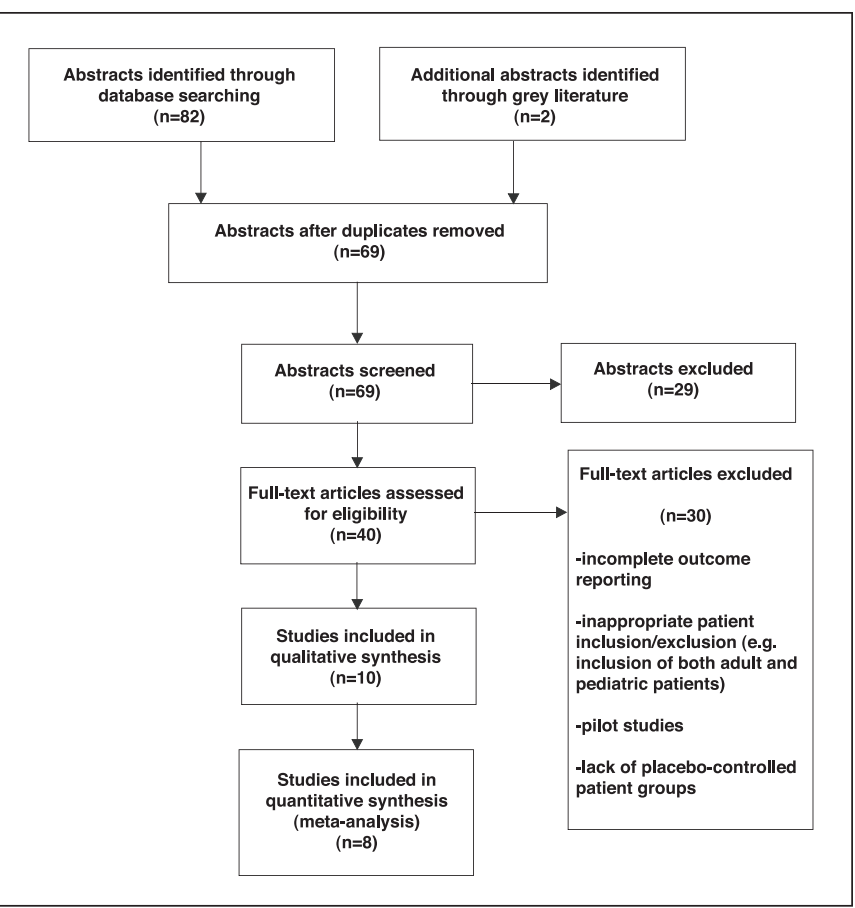

Figure 1: Flow Diagram of Study Selection. inadequate. Regarding allocation concealment, it was classified as adequate if participants and the investigators enrolling participants could not foresee assignment. Allocation concealment was unclear if the method used was not described. Concealment was inadequate if participants and investigators enrolling participants could foresee upcoming assignment. Inclusion of all randomized participants (proportion of participants included for which an efficacy endpoint is available) was classified as adequate (if $\geq 90 \%$ ), inadequate (if $<90 \%$ ), or unclear. Disagreements were resolved by consensus.

\section{Additional Analyses}

A funnel plot was constructed to look for evidence of publication bias $^{9}$. Sensitivity analyses were conducted to test for robustness of findings.

Table 1: Characteristics of excluded studies

\begin{tabular}{l|l}
\hline Study & Reasons for exclusion. \\
\hline Berkovic, et al. $2007^{10}$ & Inclusion of pediatric population. \\
\hline Jones, et al. $2008^{11}$ & Prospective cohort study. \\
\hline Lim, et al. $2009^{12}$ & $\begin{array}{l}\text { Pilot feasibility study, no } \\
\text { appropriate control group. }\end{array}$ \\
\hline Milligan, et al. $2008^{13}$ & Retrospective cohort study. \\
\hline Noachtar, et al. $2008^{14}$ & Inclusion of pediatric population. \\
\hline Steinhoff, et al. $2007^{15}$ & $\begin{array}{l}\text { Open label study, no appropriate } \\
\text { control group. }\end{array}$ \\
\hline
\end{tabular}

\section{RESULTS}

\section{Study Selection}

There were 82 citations originally identified in our literature search (Figure 1). Abstract screening yielded 40 full text articles for assessment, with ten meeting our inclusion criteria. Reasons for exclusion included: incomplete/inappropriate outcome reporting, inappropriate patient groups, as well as pilot studies also reported in full. Eight studies, investigating the effects of 
add-on levetiracetam, were included in our meta-analyses. Two other studies were included in our qualitative synthesis, one using levetiracetam as prophylactic agent, and the other as monotherapy agent. These two studies were not included in our quantitative meta-analysis because of differences in trial administrations, time to dose escalations, and intervals of outcome assessments.

\section{Results of Individual Studies}

Results and critique, using $\mathrm{GRADE}^{7}$ criteria, of each study are as included in the "Characteristics of included studies," and "Characteristics of excluded studies" tables.

\section{Study Characteristics}

The eight included randomized controlled trials (RCTs) investigating adjunctive levetiracetam included patients with seizure types including simple partial seizures, complex partial seizures, partial seizures with secondary generalization, as well as primary generalized tonic-clonic seizures. These randomized trials investigated the effects of levetiracetam across multiple dosages and formulations, namely, $1000 \mathrm{mg} / \mathrm{day}, 2000 \mathrm{mg} / \mathrm{day}$, $3000 \mathrm{mg} /$ day, $4000 \mathrm{mg} /$ day; as well as extended release formulations.

While not included in the quantitative synthesis, the single RCT investigating monotherapy levetiracetam as prophylactic agent (Szaflarski 2010 ${ }^{16}$ ) points to its potential role for seizure prevention post traumatic brain injury. In this study, levetiracetam seems to be as effective as phenytoin for seizure prophylaxis ( $p$ value for difference in efficacy $=0.85$ ), with fewer side effects $(\mathrm{p}=0.02)$.

Similarly, the single RCT investigating monotherapy levetiracetam treatment agent (Brodie 2007 ${ }^{17}$ ) points to its potential role for newly diagnosed, rather than treatmentresistant, epilepsy. In this study, levetiracetam seems to be as effective as carbamazepine CR for treatment of newly diagnosed seizures ( $\mathrm{p}$ value for difference in efficacy $=1.00$ ), with nonsignificant difference in side effect profile of the two medications $(\mathrm{p}=0.12)$. This latter study had clear randomization techniques, blinding, as well as allocation concealment.

Table 2: Assessment of methodological quality for included studies

\begin{tabular}{l|l|l|l|l}
\hline Trial & Randomization & Concealment & Blinding & $\begin{array}{l}\text { Percentage of } \\
\text { randomized } \\
\text { patients } \\
\text { included in trial }\end{array}$ \\
\hline Ben-Menachem $2000^{18}$ & Likely done & Unclear & Double blind & $95 \%$ \\
\hline Shorvon $2000^{19}$ & Likely done & Adequate & Double blind & $100 \%$ \\
\hline Cereghino $2000^{1}$ & Adequate & Adequate & Double blind & $100 \%$ \\
\hline Peltola $2009^{20}$ & Adequate & Adequate & Double blind & $100 \%$ \\
\hline Xiao $2009^{21}$ & Adequate & Adequate & Double blind & $100 \%$ \\
\hline Wu $2009^{22}$ & Likely done & Unclear & Double blind & $100 \%$ \\
\hline Tsai $2006^{23}$ & Adequate & Adequate & Double blind & $100 \%$ \\
\hline Betts $2000^{24}$ & Adequate $2007^{17}$ & Adequate & Double blind & $100 \%$ \\
\hline
\end{tabular}

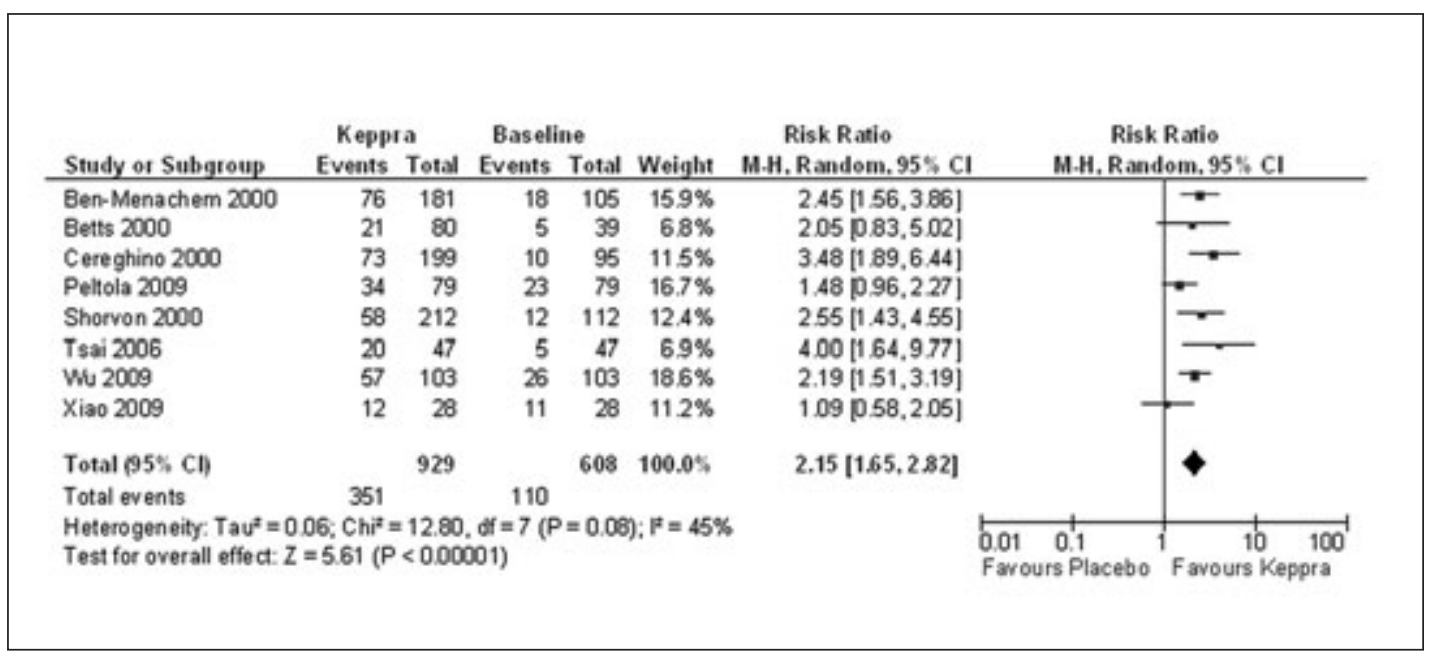

Figure 2: Forest plot combining eight RCTs using levetiracetam as adjunctive agent in achieving at least $50 \%$ seizure reduction. Here, various dosages have been combined. Subsequent meta-analyses performed using each dosing regimen. 
Table 3: GRADE evidence profile for levetiracetam and epilepsy

\begin{tabular}{|c|c|c|c|c|c|c|c|c|c|c|c|c|}
\hline \multirow{2}{*}{\multicolumn{7}{|c|}{ Quality assessment }} & \multicolumn{5}{|c|}{ Summary of findings } & \multirow[b]{3}{*}{ Importance } \\
\hline & & & & & & & \multicolumn{2}{|c|}{ No of patients } & \multicolumn{2}{|c|}{ Effect } & \multirow[b]{2}{*}{ Quality } & \\
\hline $\begin{array}{l}\text { No of } \\
\text { studies }\end{array}$ & Design & Limitations & Inconsistency & Indirectness & Imprecision & $\begin{array}{c}\text { Other } \\
\text { considerations }\end{array}$ & $\begin{array}{c}\text { levetiracetam (a } \\
\text { adjunctive or } \\
\text { monotherapy) }\end{array}$ & is $\begin{array}{c}\text { placebo or } \\
\text { baseline } \\
\text { antiepileptics }\end{array}$ & $\begin{array}{c}\text { Relative } \\
(95 \% \text { CI })\end{array}$ & Absolute & & \\
\hline \multicolumn{13}{|c|}{ Adequate response ( $\geq 50 \%$ responder rate; follow-up median 26 weeks) } \\
\hline 8 & $\begin{array}{c}\text { randomized } \\
\text { trials }\end{array}$ & serious $^{1}$ & \begin{tabular}{|c|} 
no serious \\
inconsistency
\end{tabular} & \begin{tabular}{|c|} 
no serious \\
indirectness
\end{tabular} & $\begin{array}{c}\text { no serious } \\
\text { imprecision }\end{array}$ & $\begin{array}{c}\text { reporting bias }^{2} \\
\text { strong association }\end{array}$ & $351 / 929(37.8 \%)$ & $110 / 608(18.1 \%)$ & $\begin{array}{c}\text { RR } 2.15 \\
\text { (1.65 to } 2.82)\end{array}$ & $\begin{array}{c}208 \text { more per } \\
1000 \text { (from } 118 \\
\text { more to } 329 \\
\text { more) }\end{array}$ & MODERATE & CRITICAL \\
\hline \multicolumn{13}{|c|}{ Serious Adverse Events Requiring Withdrawal from Study (follow-up mean 26 weeks) } \\
\hline 8 & $\begin{array}{c}\text { randomized } \\
\text { trials }\end{array}$ & serious $^{4}$ & \begin{tabular}{c|} 
no serious \\
inconsistency
\end{tabular} & $\begin{array}{l}\text { no serious } \\
\text { indirectness }\end{array}$ & $\begin{array}{c}\text { no serious } \\
\text { imprecision }\end{array}$ & $\begin{array}{c}\text { reporting bias }^{5} \\
\text { strong association }\end{array}$ & $47 / 687(6.8 \%)$ & $29 / 607(4.8 \%)$ & $\begin{array}{c}\text { RR } 1.37 \\
(0.88 \text { to } 2.13)\end{array}$ & $\begin{array}{c}18 \text { more per } \\
1000 \text { (from } 6 \\
\text { fewer to } 54 \\
\text { more) }\end{array}$ & MODERATE & IMPORTANT \\
\hline
\end{tabular}

Question: Should adjunctive levetiracetam versus placebo be used for epilepsy? Settings: urgent and non-urgent care. Bibliography: BenMenachem 2000, Betts 2000, Cereghino 2000, Peltola 2009, Shorvon 2000, Tsai 2006, Wu 2009, Xiao 2009; ${ }^{1}$ lack of allocation concealment in two of eight studies (Ben-Menachem 2000, Wu 2009); ${ }^{2}$ all studies were funded by drug manufacturer; ${ }^{3}$ Overall RR $=2.15$, with $95 \%$ CI of $1.65,2.82$; overall effect $\mathrm{Z}=5.61, \mathrm{p}<0.00001 ;{ }^{4}$ lack of allocation concealment in two of eight studies (Ben-Menachem 2000, Wu 2009); ${ }^{5}$ all studies were funded by drug manufacturer; ${ }^{6}$ Overall $\mathrm{RR}=1.37(0.88,2.13)$, I-squared $=0 \%$, $\mathrm{p}$ value for heterogeneity $=0.84$, $\mathrm{p}$ value for overall effect $=0.17$; indicating lack of difference in side effects from keppra versus placebo

\section{Assessment of Methodological Quality for Included Studies}

For the eight included RCTs, five had clear descriptions of randomization techniques, and two had unclear concealment. They were all double-blind studies. All, except one, included all randomized patients in the trials (Table 2). Table 3 shows the GRADE Evidence Profile for levetiracetam.

\section{Synthesis of Results}

Meta-analysis of the included eight RCTs (intention-to-treat principle) showed that adjunctive levetiracetam was more effective than placebo in achieving at least $50 \%$ reduction of seizures, when added to baseline regimen of antiepileptics. With combination of these eight studies, the $\mathrm{I}^{2}$ value was $45 \%$ (moderate heterogeneity) (Figure 2). One study (Xiao 200921), however, contributed to much of the heterogeneity. We note that this study included post-surgical patients with refractory epilepsy, as well as patients with much lower mean body weight. One notes that patient's pharmacokinetic profile, and thus, his or her response to the medication, may differ, if less than 50 kilograms ${ }^{21}$. Sensitivity analysis with exclusion of this study yields an $\mathrm{I}^{2}$ of $24 \%$, noting mild heterogeneity in the remaining seven RCTs (with $\mathrm{p}$ value for heterogeneity $=0.25$, and $\mathrm{p}$ value for overall effect size < 0.01) (Figure 3).

Different dosages (1000 mg/day, $2000 \mathrm{mg} /$ day, $3000 \mathrm{mg} /$ day, and $4000 \mathrm{mg} / \mathrm{day}$ ) and formulations (traditional and extended release) are amenable to quantitative combination in our metaanalysis. Subgroup analyses (specified $a$ priori) were performed across the different dosages. Similar $95 \%$ confidence intervals, favouring levetiracetam, were demonstrated (Figures 4-6).

Treatment-emergent adverse events include somnolence, irritability, headaches, dizziness, respiratory tract infections, and nausea. Incidences of these adverse events are not significantly more frequent than those seen in patients with baseline regimen of several antiepileptic agents. Likelihood of serious adverse events from adjunctive levetiracetam necessitating withdrawal from study was not significantly different those on adjunctive placebo (pooled RR $1.37[0.88,2.13], \mathrm{I}^{2}=0 \%$, p value for heterogeneity $-0.84, \mathrm{p}$ value for overall effect $=0.17$ ) (Figure 7). These serious adverse events included rash, worsening of seizure frequency, and blood dyscrasias.

\section{Additional Analysis}

Sensitivity analysis was done to include randomized trials that had adequate allocation concealment. The resultant relative risk, $95 \%$ confidence interval, $\mathrm{I}^{2}$ value for heterogeneity are similar to meta-analysis completed with all eight randomized trials (Figure 8).

\section{Discussion}

\section{Summary of Evidence, with Implications for Clinical Practice and Research}

Levetiracetam is an antiepileptic medication with a novel mechanism, with a favourable pharmacokinetic profile, and minimal drug-drug interactions. Prior systematic reviews established its role as an adjunctive agent for treatment of refractory partial seizures. In this systematic review and metaanalyses, levetiracetam is established as an effective adjunctive agent for control of refractory epilepsy. It seems to be effective at doses from $1000 \mathrm{mg}$ per day to $3000 \mathrm{mg}$ per day, titrated to effect. Clinically, one notes that the converse is also possible, in that a patient not responding to a medium dose of levetiracetam 


\begin{tabular}{|c|c|c|c|c|c|c|c|c|}
\hline \multirow{2}{*}{$\begin{array}{l}\text { Study or Subgroup } \\
\text { Ben-Menachem } 2000\end{array}$} & \multicolumn{2}{|c|}{ Keppra } & \multicolumn{2}{|c|}{ Baseline } & \multirow{2}{*}{$\begin{array}{r}\text { Weight } \\
18.6 \%\end{array}$} & \multirow{2}{*}{$\begin{array}{c}\begin{array}{c}\text { Risk Ratio } \\
\text { M.H, Random, } 95 \% \mathrm{Cl}\end{array} \\
2.45[1.56,3.86]\end{array}$} & \multicolumn{2}{|c|}{$\begin{array}{c}\text { Risk Ratio } \\
\text { M.H, Random, } 95 \% \mathrm{Cl}\end{array}$} \\
\hline & 76 & 181 & 18 & 105 & & & & $\rightarrow-$ \\
\hline Betts 2000 & 21 & 80 & 5 & 39 & $6.2 \%$ & 2.05 [083.5.02] & & $\because$ \\
\hline Cereghino 2000 & 73 & 199 & 10 & 95 & $118 \%$ & $3.48[189,6.44]$ & & $\rightarrow$ \\
\hline Pello la 2009 & 34 & 79 & 23 & 79 & $20.2 \%$ & 1.48 p.96.2.27] & & - \\
\hline Showron 2000 & 58 & 212 & 12 & 112 & $13.0 \%$ & $255[1.43 .4 .55]$ & & $\rightarrow$ \\
\hline Tsai2006 & 20 & 47 & 5 & 47 & $6.2 \%$ & $4.00[1.64,9.77]$ & & $\longrightarrow$ \\
\hline Wu 2009 & 57 & 103 & 26 & 103 & $23.9 \%$ & $2.19[1.51,3.19]$ & & $*$ \\
\hline Total $(95 \% \mathrm{Cl})$ & & 901 & & 580 & 100.05 & $2.30[1.82,2.91]$ & & $\bullet$ \\
\hline Total events & 339 & & 99 & & & & & \\
\hline $\begin{array}{l}\text { Heterogeneity: } \mathrm{Tau}^{2}= \\
\text { Test for overall effect }\end{array}$ & $\begin{array}{l}.02 ; \mathrm{Chi}^{2}= \\
=6.95(\mathrm{P}\end{array}$ & $\begin{array}{l}=7.69 \\
<0.00\end{array}$ & $\begin{array}{l}d f=6(P \\
001)\end{array}$ & $=0.25)$ & $P^{2}=24 \%$ & & \begin{tabular}{lc|} 
& 1 \\
0.01 & 0.1 \\
Favours Placebo
\end{tabular} & $\begin{array}{|cc|}10 & 100 \\
\text { Favours Keppra } & 10\end{array}$ \\
\hline
\end{tabular}

Figure 3: Forest plot, excluding Xiao study ${ }^{21}$, which contributed to overall study heterogeneity. Seven RCTs using levetiracetam as adjunctive agent in achieving at least 50\% seizure reduction.

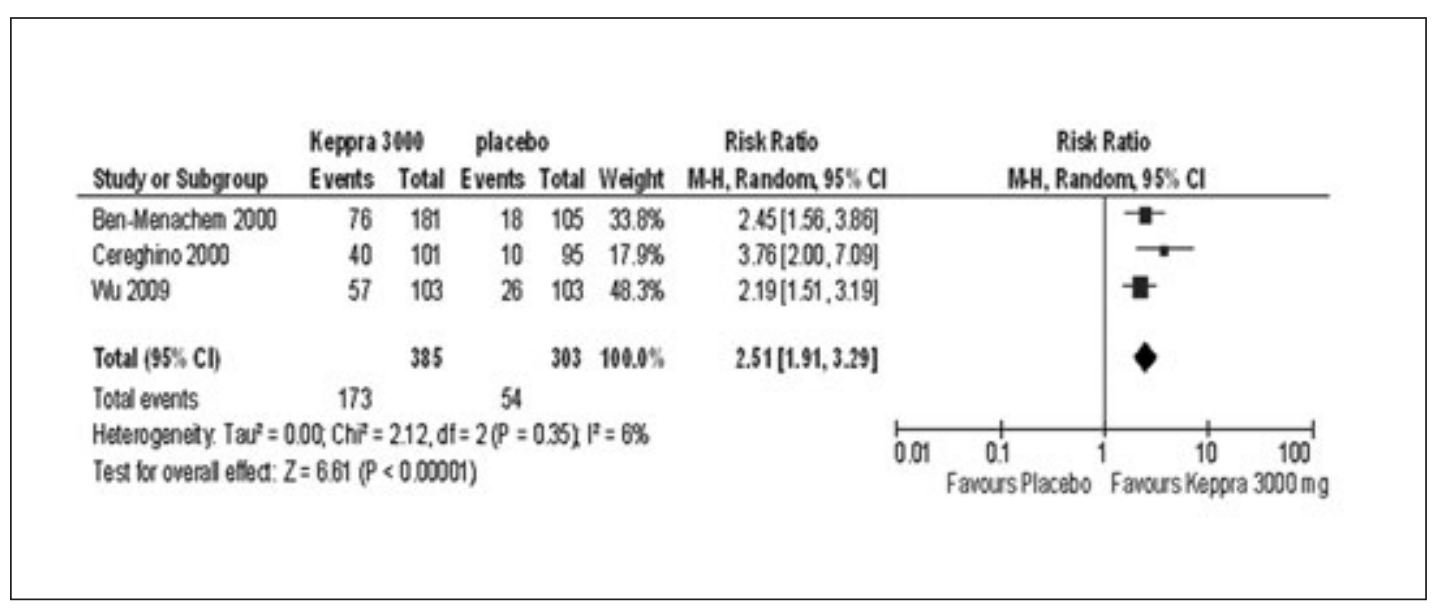

Figure 4: Forest plot, of adjunctive levetiracetam at $3000 \mathrm{mg} / \mathrm{d}$ in achieving at least $50 \%$ seizure reduction.

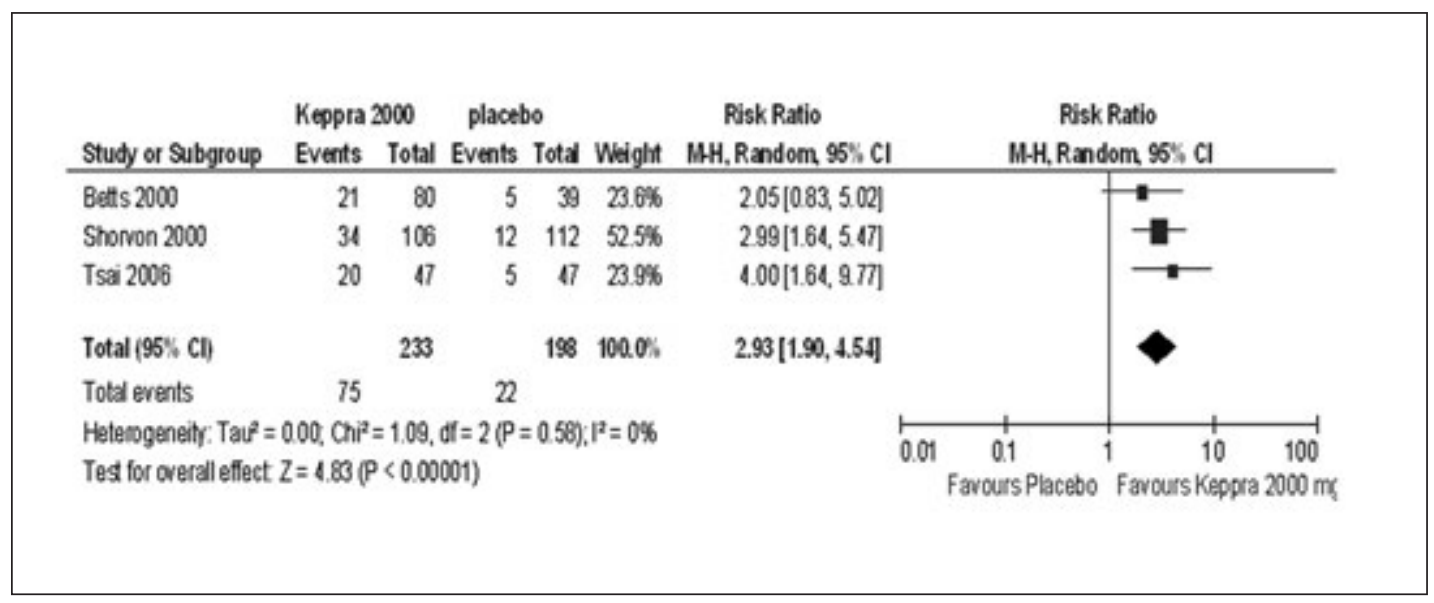

Figure 5: Forest plot, of adjunctive levetiracetam at $2000 \mathrm{mg} / \mathrm{d}$ in achieving at least $50 \%$ seizure reduction. 


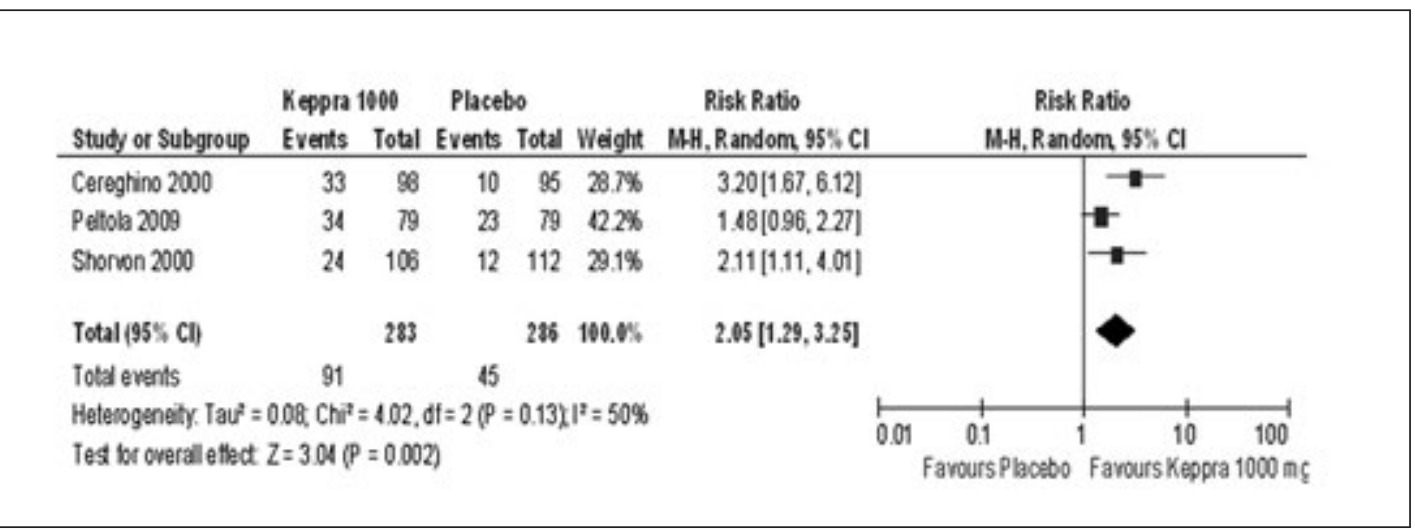

Figure 6: Forest plot, of adjunctive levetiracetam at $1000 \mathrm{mg} / \mathrm{d}$ in achieving at least $50 \%$ seizure reduction.

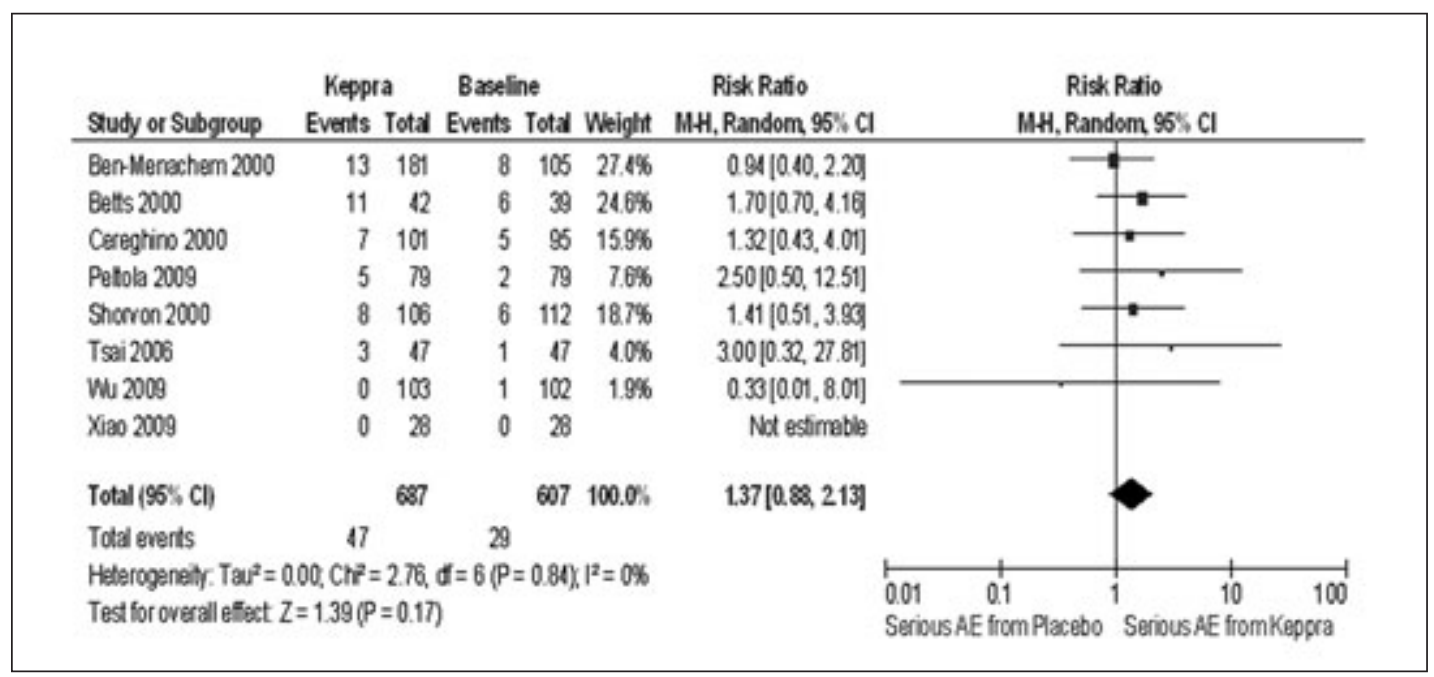

Figure 7: Forest plot of serious adverse events from adjunctive levetiracetam requiring withdrawal from study.

\begin{tabular}{|c|c|c|c|c|c|c|c|}
\hline \multirow[b]{2}{*}{ Study or Subgroup } & \multicolumn{2}{|c|}{ Keppra } & \multicolumn{2}{|c|}{ Baseline } & \multirow[b]{2}{*}{ Weight } & \multirow{2}{*}{$\begin{array}{c}\text { Risk Ratio } \\
\text { M-H, Random, } 95 \% \mathrm{Cl}\end{array}$} & \multirow{2}{*}{$\begin{array}{c}\text { Risk Ratio } \\
\text { M.H, Random, } 95 \% \mathrm{Cl} \\
\end{array}$} \\
\hline & Events & Total & Events & Total & & & \\
\hline Betts 2000 & 21 & 20 & 5 & 39 & $137 \%$ & $2.05[0.83,5.02]$ & $\because$ \\
\hline Cereghino 2000 & 73 & 199 & 10 & 95 & $21.3 \%$ & $3.48[1.89,6.44]$ & $\mp$ \\
\hline Peltola 2009 & 34 & 79 & 23 & 79 & $286 \%$ & $1.48[0.96 .2 .27]$ & + \\
\hline Shorvon 2000 & 58 & 212 & 12 & 112 & $226 \%$ & $2.55[1.43,4.55]$ & $\rightarrow$ \\
\hline Tsail2006 & 20 & 47 & 5 & 47 & $13.8 \%$ & $4.00[1.64,9.77]$ & $\longrightarrow$ \\
\hline Total $(95 \mathrm{YCl})$ & & 617 & & 372 & $100.0 \%$ & $2 A 1[1.51,3.60]$ & 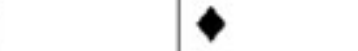 \\
\hline Total events & 206 & & 55 & & & & \\
\hline $\begin{array}{l}\text { Heterogeneity: } \text { Tau }^{2}= \\
\text { Test for overall effect: }\end{array}$ & $\begin{array}{l}0.10 ; \mathrm{Chi}^{2} \\
\mathrm{z}=4.27 \mathrm{if}\end{array}$ & $\begin{array}{l}=7.86 . \\
P<0.00\end{array}$ & $\begin{array}{l}d f=4(P \\
001)\end{array}$ & $=0.10$ & b) $F^{2}=49 \%$ & & 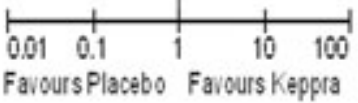 \\
\hline
\end{tabular}

Figure 8: Sensitivity analysis - forest plot of studies with adequate allocation concealment. 


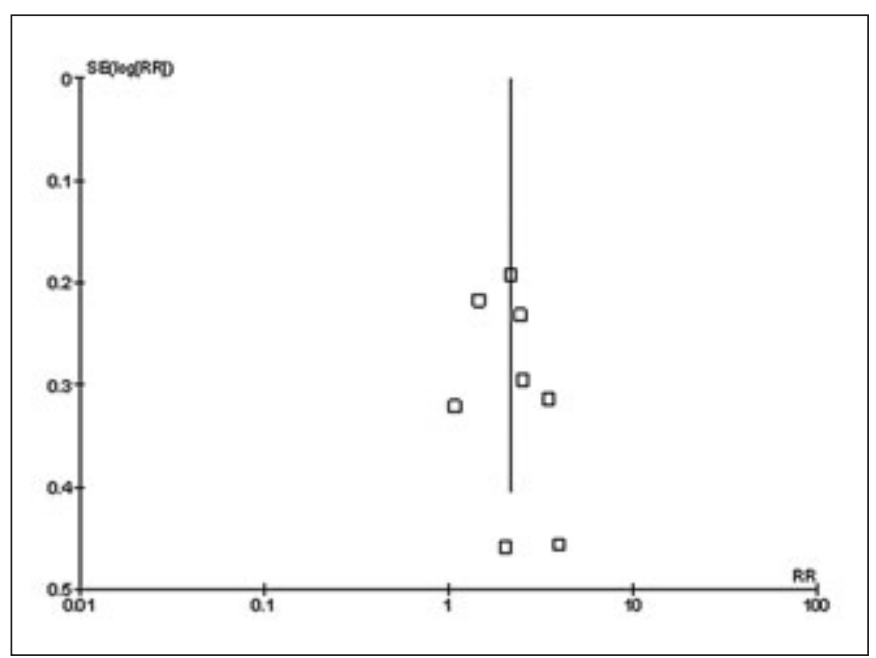

Figure 9: Funnel plot of eight included RCTs.

may not exhibit seizure reduction with dose escalation. More importantly, our study shows that it is effective across multiple seizure types, including simple partial, complex partial, partial seizure with secondary generalization, as well as generalized tonic-clonic seizures. Patients, when taking this medication as an adjunctive agent to baseline regimen of antiepileptic medications, do not seem to have increased side effects attributable to levetiracetam. Because of lack of allocation concealment in two of eight studies, as well as publication bias, the overall quality of evidence is moderate. Yet, the results of this study are of high level of importance for patient management. The robustness of meta-analysis results remained intact when studies with adequate allocation concealment were entered into the sensitivity analyses.

Overall, the quantitative synthesis showed mild to moderate heterogeneity, depending on whether all studies were included. Causes of heterogeneity may include: drug-drug interactions from baseline antiepileptics, different seizure subtypes, varying duration and severity of disease, length and rate of drug titration, and different week number for evaluation. One study (Xiao $2009^{21}$ ), in particular, contributed to much of the heterogeneity. We note that the mean body weights in this study was significantly lower that those form other studies, noting a possible different pharmacokinetic profile of the drug in those who weigh less than 50 kilograms. In addition, the Xiao study included patients who underwent epilepsy surgery. When compared to the non-surgical patient population, the surgical group with refractory epilepsy may exhibit different response profiles to re-introduction and dose adjustments of multiple antiepileptics, including levetiracetam, after resection of epileptic foci. Confounding factors in the surgical group include hemosiderin deposition, cortical scarring and occurrence of the rekindling phenomenon.

Although not sufficient for quantitative synthesis, two stand alone trials investigating the role of levetiracetam as monotherapy agents point to its possible efficacy in treating newly diagnosed epilepsy of all types, as well as its role in preventing seizures in those with post-traumatic brain injury. Further studies are currently underway to further investigate these roles. In addition, further studies are needed to investigate the long-term efficacy and safety of the use of this medication.

\section{Risk of Bias Within Studies}

Within each study, patients kept their own seizure diaries. Thus, self reporting bias is inherent within each trial, as there is no standardized system for reporting, except in the $\mathrm{Wu}$ study ${ }^{22}$. In addition, one study (Xiao study ${ }^{21}$ ) had observers to verify seizures. In the patients' follow-up visits, only semi-structured interviews were used, with no standardized questionnaires to ensure the accuracy of both seizure numbers, types and durations.

Contamination bias is also possible, as the number and types of baseline agents vary for each patient. Although levetiracetam is not known to have drug-drug interactions with other antiepileptics, these interactions exist between baseline agents used. It is, therefore, very difficult to design a study to measure the pure effects of levetiracetam.

Self-reporting bias also comes into play with reporting of adverse events. Entities such as asthenia, as reported by patients themselves, are subjective and not amenable to objective grading.

\section{Publication Bias}

Presence of asymmetric funnel plot was noted. This asymmetry can be a chance finding when there are fewer than ten studies included in the scatter plot (Daya 2006 9 ), (Figure 9).

\section{Limitations}

The major limitations of this systematic review and metaanalysis include potential publication bias, patient self-reporting bias from lack of standardized seizure diaries and follow-up interviews, contamination from multiple drug-drug interactions, and differing durations of evaluation periods from included studies. One also notes that treatment of each epileptic patient is individualized, depending on the patient's age, duration and severity of disease, response to various medications and surgical interventions, tolerance to medication side effects, and compliance to treatment. Long-term follow-up is needed to investigate the medication's safety and efficacy, as single or adjunctive agent.

\section{Conclusions}

Our systematic review and meta-analyses establish levetiracetam as an effective add-on agent for refractory epilepsy, across all seizure types. More studies are needed to establish whether levetiracetam is an effective agent for monotherapy for treatment of newly diagnosed seizures and for prophylaxis of seizures in the traumatic brain injury population. Long-term studies will be useful in elucidating its continued safety and efficacy. 


\section{REFERENCES}

1. Cereghino J, Biton V, Abou-Khalil B, et al. Levetiracetam for partial seizures - results of a double-blind, randomized clinical trial. Neurology. 2000;55:236-42.

2. French J, Edrich P, Cramer J. A systematic review of the safety profile of levetiracetam: a new antiepileptic drug. Epilepsy Res. 2001;47:77-90.

3. Leppik I, Morrell M, Godfroid P, et al. Seizure-free days observed in randomized placebo-controlled add-on trials with levetiracetam in partial epilepsy. Epilepsia. 2003;44(10):1350-2.

4. Otoul C, Arrigo C, van Rijckevorsel, et al. Meta-analysis and indirect comparisons of levetiracetam with other secondgeneration antiepileptic drugs in partial epilepsy. Clin Neuropharmacol. 2005;28(2):72-8.

5. Cramer J, De Rue K, Devinsky O, et al. A systematic review of the behavioural effects of levetiracetam in adults with epilepsy, cognitive disorders, or an anxiety disorder during clinical trials. Epilepsy Behav. 2003;4:124-32.

6. Higgins JPT, Green S, editors. Cochrane Handbook for Systematic Reviews of Interventions Version 5.0.2. The Cochrane Collaboration [cited 2009 Sep 29]. Available from www.cochrane- handbook.org.

7. Guyatt G, Oxman A, Vist G, et al. GRADE: an emerging consensus on rating quality of evidence and strength of recommendations. BMJ. 2008;336:924-7.

8. Schunemann H, Jaeschke R, Cook D, et al. An official ATS statement: grading the quality of evidence and strength of recommendations in ATS guidelines and recommendations. Am J Respir Crit Care Med. 2006;174(5):605-14.

9. Daya S. Funnel plots and publication bias - work in progress? Evidence-based Obstet and Gynecol. 2006;8:71-2.

10. Berkovic S, Knowlton R, Leroy R, et al. Placebo-controlled study of levetiracetam in idiopathic generalized epilepsy. Neurology. 2007;69:1751-60.

11. Jones K, Puccio A, Harshman K, et al. Levetiraectam versus phenytoin for seizure prophylaxis in severe traumatic brain injury. Neurosurg Focus. 2008;25(4):e1-5.

12. Lim D, Tarapore P, Chan E, et al. Safety and feasibility of switching from phenytoin to levetiracetam monotherapy for glioma-related seizure control following craniotomy: a randomized phase II pilot study. J. Neurooncol. 2009;93(3):349-54.

13. Milligan T, Hurwitz S, Bromfield E, et al. Efficacy and tolerability of levetiracetam versus phenytoin after supratentorial neurosurgery. Neurology. 2008;71:665-9.
14. Noachtar S, Andermann E, Meyvisch P, et al. Levetiracetam for the treatment of idiopathic generalized epilepsy with myoclonic seizures. Neurology. 2008;70:607-16.

15. Steinhoff B, Somerville E, van Paesschen W, et al. The SKATE study: an open-label community-based study of levetiracetam as add-on therapy for adults with uncontrolled partial epilepsy. Epilepsy Res. 2007;76(1):6-14.

16. Szaflarski J, Sangha K, Lindsell C, et al. Prospective, randomized, single-blinded comparative trial of intravenous levetiracetam versus phenytoin for seizure prophylaxis. Neurocrit Care. 2010; 12(2):165-72.

17. Brodie M, Perucca E, Ryvlin P, et al. Comparison of levetiracetam and controlled-release carbamazepine in newly diagnosed epilepsy. Neurology. 2007;68:402-8.

18. Ben-Menachem E, Falter U. Efficacy and tolerability of levetiracetam $3000 \mathrm{mg} / \mathrm{d}$ in patients with refractory partial seizures: a multicenter, double-blind, responder-selected study evaluating monotherapy. Epilepsia. 2000;41(10):1276-83.

19. Shorvon S, Löwenthal A, Janz D, et al. Multicenter double-blind, randomized, placebo-controlled trial of levetiracetam as add-on therapy in patients with refractory partial seizures. Epilepsia. 2000;41(9): 1179-86.

20. Peltola J, Coetzee C, Jimenez F, et al. Once-daily extended-release levetiracetam as adjunctive treatment of partial-onset seizures in patients with epilepsy: a double-blind, randomized, placebocontrolled trial. Epilepsia. 2009;50(3):406-14.

21. Xiao Z, Li J-M, Wang X-F, et al. Efficacy and safety of levetiracetam ( $3000 \mathrm{mg} /$ day) as an adjunctive therapy in Chinese patients with refractory partial seizures. Eur Neurol. 2009;61: 233-9.

22. Wu X-Y, Hong Z, Wu X, et al. Multicenter double-blind, randomized, placebo-controlled trial of levetiracetam as add-on therapy in Chinese patients with refractory partial-onset seizures. Epilepsia. 2009;50(3):398-405.

23. Tsai J-J, Yen D-J, Hsih M-S, et al. Efficacy and safety of levetiracetam (up to $2000 \mathrm{mg} /$ day) in Taiwanese patients with refractory partial seizures: a multicenter, randomized, doubleblind, placebo-controlled study. Epilepsia. 2006;47(1):72-81.

24. Betts T, Waegemans T, Crawford P. A multicenter, double-blind, randomized, parallel group study to evaluate to the tolerability and efficacy of two oral doses of levetiracetam, $2000 \mathrm{mg}$ daily and $4000 \mathrm{mg}$ daily, without titration in patients with refractory epilepsy. Seizure. 2000;9:80-7. 


\section{APPENDIX \\ Characteristics of Included Studies}

\begin{tabular}{|c|c|}
\hline Study 1 & Ben-Menachem $2000^{18}$ \\
\hline Methods & $\begin{array}{l}\text { Multi-center, randomized, double-blind, parallel-group, responder- } \\
\text { selected study. } \\
\text { Double blinding during add-on therapy phase. } \\
\text { Loss to follow up: } 2 \text { patients. }\end{array}$ \\
\hline Participants & $\begin{array}{l}\text { Patients recruited between June } 1995 \text { and March } 1997 \text { in } 47 \text { European institutions. } \\
\text { Seizure types included: simple partial seizures, complex partial seizures, and secondarily generalized seizures. } \\
\text { Mean body mass index }=24.5 \mathrm{~kg} / \mathrm{m}^{2}(\mathrm{SD}=4) \text {. } \\
\text { At up-titration phase - placebo }(\mathrm{N}=105) \text {, treatment }(\mathrm{N}=181) \text {. }\end{array}$ \\
\hline Interventions & $\begin{array}{l}12 \text { week baseline. Then, randomization. Up-titration for } 4 \text { weeks, to one baseline antiepileptic plus Keppra } \\
3000 \mathrm{mg} / \mathrm{d} \text { or placebo. Add-on evaluation for } 14 \text { weeks. If possible, down titration to monotherapy. }\end{array}$ \\
\hline Outcomes & Median percentage seizure reduction, $>50 \%$ responder rate, number reaching seizure freedom, adverse events. \\
\hline Randomization & Likely done \\
\hline Allocation Concealment & Unclear \\
\hline Blinding & Double-blind (patients, outcome assessors) \\
\hline
\end{tabular}

\begin{tabular}{|c|c|}
\hline Study 2 & Shorvon $2000^{19}$ \\
\hline Methods & Multi-center, randomized, double-blind, placebo-controlled parallel group. Loss to follow-up: none. \\
\hline Participants & $\begin{array}{l}\text { Patients recruited from } 61 \text { sites from Europe and the UK. } \\
\text { Seizure types included: simple partial seizures, complex partial seizures, partial seizures with secondary } \\
\text { generalization. } \\
\text { Mean weight }=71.5 \mathrm{~kg} \text {. } \\
\text { At up-titration phase }- \text { placebo }(\mathrm{N}=112) \text {, treatment }(\mathrm{N}=106 \text { in } \\
\text { Keppra } 1000 \mathrm{mg} / \mathrm{d} ; \mathrm{N}=106 \text { in Keppra } 2000 \mathrm{mg} / \mathrm{d}) .\end{array}$ \\
\hline Interventions & $\begin{array}{l}12 \text { week baseline. Then, randomization. 4-week up-titration, with } 12 \text {-week treatment period (baseline } \\
\text { antiepileptics, and placebo, or Keppra } 1000 \mathrm{mg} / \mathrm{d} \text {, or Keppra } 2000 \mathrm{mg} / \mathrm{d} \text { ) }\end{array}$ \\
\hline Outcomes & $\begin{array}{l}\text { Primary - mean number of partial seizures per week during evaluation period (seizure frequency); secondary- } \\
>50 \% \text { responder rate, incidence of seizure-free patients, adverse events. }\end{array}$ \\
\hline Randomization & Likely done \\
\hline Allocation Concealment & Adequate (identical packaging, identical looking drug and placebo) \\
\hline Blinding & Double-blind (patients, outcome assessors) \\
\hline Study 3 & Cereghino $2000^{1}$ \\
\hline Methods & $\begin{array}{l}\text { Multi-center, randomized, add-on, double-blind, placebo-controlled, parallel-group trial. Double blind titration } \\
\text { and treatment period. Loss to follow-up: } 3 \text { patients. }\end{array}$ \\
\hline Participants & $\begin{array}{l}\text { Patients recruited between September } 1994 \text { and March } 1996 \text { in } 41 \\
\text { institutions. } \\
\text { Seizure types included: partial seizures with or without secondary generalization. } \\
\text { Mean weight }=78.5 \mathrm{~kg} \text {. } \\
\text { At up-titration phase }- \text { placebo }(\mathrm{N}=95) \text {, treatment }(\mathrm{N}=98 \text { in Keppra } 1000 \mathrm{mg} / \mathrm{d} ; \mathrm{N}=101 \text { in Keppra } 3000 \\
\mathrm{mg} / \mathrm{d}) .\end{array}$ \\
\hline Interventions & $\begin{array}{l}12 \text { week baseline. Then, randomization. 4-week up-titration to 14-week treatment. Treatment groups: } \\
\text { baseline antiepileptics + placebo, or Keppra } 500 \mathrm{mg} \text { BID, or Keppra } 1500 \mathrm{mg} \text { BID. Then, withdrawal or entry } \\
\text { into follow-up study at week } 30 \text {. }\end{array}$ \\
\hline Outcomes & $\begin{array}{l}\text { Primary - mean number of partial seizures per week (over } 14 \text {-week } \\
\text { evaluation period); secondary - mean percent reduction, }>50 \% \text { responder } \\
\text { rate, number of seizure-free patients, adverse events. }\end{array}$ \\
\hline Randomization & Adequate (block randomization) \\
\hline Allocation Concealment & Adequate (identical looking and tasting tablets, identical packaging) \\
\hline Blinding & Double-blind (patients, investigators) \\
\hline
\end{tabular}

\begin{tabular}{|c|c|}
\hline Study 4 & Peltola $2009^{20}$ \\
\hline Methods & $\begin{array}{l}\text { Multi-center, randomized (1:1), placebo-controlled, double-blind, trial. } \\
\text { Double blind titration and treatment period. Loss to follow-up: } 1 \text { patient. }\end{array}$ \\
\hline Participants & $\begin{array}{l}\text { Patients recruited from August } 2006 \text { to May } 2007 \text { from seven countries. } \\
\text { Seizure types included: partial seizures with or without secondary generalization. } \\
\text { Mean weight }=68.5 \mathrm{~kg} \text {. } \\
\text { At up-titration phase }- \text { placebo }(\mathrm{N}=79) \text {, treatment }(\mathrm{N}=79 \text { in Keppra XR } 1000 \mathrm{mg} / \mathrm{d}) \text {. }\end{array}$ \\
\hline Interventions & $\begin{array}{l}8 \text { week baseline, } 12 \text { weeks treatment with add-on Keppra XR } 500 \text { twice daily versus placebo, } 2 \text { weeks } \\
\text { evaluation. }\end{array}$ \\
\hline Outcomes & $\begin{array}{l}\text { Primary -frequency of partial onset seizure per week over treatment period; secondary }-50 \% \text { reduction in } \\
\text { seizure frequency per week, absolute and percentage reduction in seizure frequency per week from baseline, } \\
\text { adverse events. }\end{array}$ \\
\hline Randomization & Adequate (interactive voice response system) \\
\hline Allocation Concealment & Adequate (identical shape, size, taste, colour, packaging of placebo and treatment) \\
\hline Blinding & Double-blind (all study personnel, participants) \\
\hline
\end{tabular}




\section{APPENDIX \\ Characteristics of Included Studies (continued)}

\begin{tabular}{|c|c|}
\hline Study 5 & Xiao $2009^{21}$ \\
\hline Methods & $\begin{array}{l}\text { Randomized, double-blind, placebo-controlled, trial. Double blind titration and treatment period. Loss to } \\
\text { follow-up: none. }\end{array}$ \\
\hline Participants & $\begin{array}{l}\text { Patients recruited from single center over } 4 \text { months. } \\
\text { Those with prior epilepsy surgery who failed to reduce seizure frequency included in trial. } \\
\text { Seizure types included: partial seizures with or without secondary generalization. } \\
\text { Mean weight }=58 \mathrm{~kg} \text { (note: significantly lower than other trials). } \\
\text { At up-titration phase - placebo }(\mathrm{N}=27) \text {, treatment }(\mathrm{N}=28 \text { in Keppra } 3000 \mathrm{mg} / \mathrm{d}) \text {. }\end{array}$ \\
\hline Interventions & $\begin{array}{l}\text { Baseline: } 8 \text { weeks. Then randomization, with } 4 \text { weeks of treatment, } 12 \text { weeks of maintenance. Up-titration to } \\
1000 \mathrm{mg} / \mathrm{d}, 2000 \mathrm{mg} / \mathrm{d}, 3000 \mathrm{mg} / \mathrm{d} \text {, each over } 2 \text { weeks. After } 24 \text { weeks, open label extension or } 4 \text {-week } \\
\text { withdrawal. }\end{array}$ \\
\hline Outcomes & $\begin{array}{l}\text { Primary - logarithmically transformed weekly frequency of partial seizures over } 16 \text { weeks; secondary - } \\
\text { absolute and percentage reduction from baseline; } 50 \% \text { responder rate, percentage change from baseline in } \\
\text { weekly frequency of partial seizures, adverse events. }\end{array}$ \\
\hline Randomization & Adequate (randomization codes generated by study sponsor) \\
\hline Allocation Concealment & Adequate (numbered opaque containers used, with identical looking placebo and treatment) \\
\hline Blinding & Double-blind (patients, outcome assessors) \\
\hline Study 6 & $\mathrm{Wu} 2009^{22}$ \\
\hline Methods & $\begin{array}{l}\text { Multi-center, randomized, double-blind, placebo-controlled, } \\
\text { parallel-group trial. Double blind titration and treatment period. } \\
\text { Loss to follow-up: } 3 \text { patients. }\end{array}$ \\
\hline Participants & $\begin{array}{l}\text { Patients recruited between July } 2004 \text { and May } 2005 \text { in } 6 \text { centers. } \\
\text { Seizure types included: simple partial, complex partial, partial seizures with generalization, primary } \\
\text { generalized. } \\
\text { Mean weight }=62 \mathrm{~kg} \text {. } \\
\text { At up-titration phase - placebo }(\mathrm{N}=103) \text {, treatment }(\mathrm{N}=103 \text { in Keppra } 1000 \mathrm{mg} / \mathrm{d} \text {; } \mathrm{N}=101 \text { in Keppra } 3000 \\
\mathrm{mg} / \mathrm{d}) \text {. }\end{array}$ \\
\hline Interventions & $\begin{array}{l}8 \text { week baseline. Then, randomization. 4-week up-titration, with 12-week maintenance. Treatment groups: } \\
\text { add-on placebo, or Keppra } 3000 \mathrm{mg} / \mathrm{d} \text { (with option of fall back to } 2000 \mathrm{mg} / \mathrm{d} \text { ). At } 16 \text { weeks, down-titration or } \\
\text { conversion to open-label long term Keppra treatment. }\end{array}$ \\
\hline Outcomes & $\begin{array}{l}\text { Primary - weekly frequency of partial-onset seizures over 16-week treatment period; secondary - weekly } \\
\text { frequency of all seizures, absolute and percentage reduction from baseline in weekly frequency of partial onset } \\
\text { and all seizures, responder rate, seizure freedom rate, adverse events. }\end{array}$ \\
\hline Randomization & Likely done \\
\hline Allocation Concealment & Unclear \\
\hline Blinding & Double-blind (patients, outcome assessors) \\
\hline Study 7 & Tsai $2006^{23}$ \\
\hline Methods & $\begin{array}{l}\text { Multi-center, randomized, double-blind, placebo-controlled, } \\
\text { parallel-group trial. Double blind titration and treatment period. } \\
\text { Loss to follow-up: none. }\end{array}$ \\
\hline Participants & $\begin{array}{l}\text { Patients recruited from five centers, beginning May } 22,2000 \text {. } \\
\text { Seizure types included: partial onset seizure, with or without secondary generalization. } \\
\text { Mean weight }=64 \mathrm{~kg} \text {. } \\
\text { At up-titration phase }- \text { placebo }(\mathrm{N}=47) \text {, treatment }(\mathrm{N}=47 \text { in Keppra } 2000 \mathrm{mg} / \mathrm{d}) \text {. }\end{array}$ \\
\hline Interventions & $\begin{array}{l}\text { 8-week baseline. Then, randomization. 2-week up-titration, then 12-week maintenance period. Treatment } \\
\text { groups: adjunctive placebo, or Keppra } 1000 \mathrm{mg} \text { BID. Then, 2-week conversion to long-term, open-label } \\
\text { Keppra therapy, or 4-week withdrawal phase. }\end{array}$ \\
\hline Outcomes & $\begin{array}{l}\text { Primary - logarithmically transformed weekly frequency of partial-onset seizures over } 14 \text {-week evaluation; } \\
\text { secondary - absolute and percentage reduction from baseline in weekly frequency of partial-onset seizures, } \\
\text { weekly frequency of total seizures, }>50 \% \text { responder rate, number of seizure free days per } 4 \text { weeks, percentage } \\
\text { change from baseline in weekly frequency of partial onset seizures, adverse events. }\end{array}$ \\
\hline Randomization & Adequate (block randomization) \\
\hline Allocation Concealment & Adequate (identical containers, with identical looking placebo and treatment) \\
\hline Blinding & Double-blind (patients, outcome assessors) \\
\hline
\end{tabular}




\section{APPENDIX \\ Characteristics of Included Studies (continued)}

\begin{tabular}{|c|c|}
\hline Study 8 & Betts $2000^{24}$ \\
\hline Methods & $\begin{array}{l}\text { Multi-center, randomized, double-blind, placebo-controlled, } \\
\text { parallel-group trial. Double blind titration and treatment period. } \\
\text { Loss to follow-up: none. }\end{array}$ \\
\hline Participants & $\begin{array}{l}\text { Seizure types included: partial or secondarily generalized, primary } \\
\text { generalized tonic-clonic seizures } \\
\text { Mean weight = not reported. } \\
\text { At up-titration phase - placebo }(\mathrm{N}=39) \text {, treatment }(\mathrm{N}=42 \text { in Keppra } 2000 \mathrm{mg} / \mathrm{d}, \mathrm{N}=38 \text { in Keppra } 4000 \\
\mathrm{mg} / \mathrm{d}) \text {. }\end{array}$ \\
\hline Interventions & $\begin{array}{l}\text { 4-week baseline. Then, randomization. 24-week treatment period, with groups: antiepileptic + placebo, or } \\
\text { Keppra } 2000 \mathrm{mg} / \mathrm{d} \text {, or Keppra } 4000 \mathrm{mg} / \mathrm{d} \text {. Then, open-label treatment period for } 24 \text { weeks, followed by } 4 \text { - } \\
\text { week run-out down-titration period, or open follow-up study. }\end{array}$ \\
\hline Outcomes & $\begin{array}{l}\text { Primary }->50 \% \text { responder after } 24 \text { weeks of treatment; secondary }->50 \% \text { responder rate after } 4 \text { weeks of } \\
\text { treatment, seizure frequency by seizure type, number of seizure free patients, adverse events. }\end{array}$ \\
\hline Randomization & Adequate (block randomization, randomization sequence) \\
\hline Allocation Concealment & Adequate (identical containers, with identical looking, tasting placebo and treatment) \\
\hline Blinding & Double-blind (patients, outcome assessors) \\
\hline Study 9 & Brodie $2007^{17}$ \\
\hline Methods & $\begin{array}{l}\text { Randomized, double-blind, parallel, group, positive-controlled monotherapy, non-inferiority trial. Double } \\
\text { blind titration and treatment period. Loss to follow-up: } 10 \text { patients. }\end{array}$ \\
\hline Participants & $\begin{array}{l}\text { Seizures included newly diagnosed partial or generalized seizures with clear focal origin or generalized tonic- } \\
\text { clonic seizures without clear focal origin. } \\
\text { Mean weight }=73.7 \mathrm{~kg} \text {. } \\
\text { At up-titration phase }- \text { Keppra }(\mathrm{N}=288) \text {, Tegretol CR }(\mathrm{N}=291) \text {. }\end{array}$ \\
\hline Interventions & $\begin{array}{l}\text { Baseline of } 1 \text { week, 2-week titration (Keppra at } 500 \mathrm{mg} / \mathrm{d} \text {, versus Tegretol at } 200 \mathrm{mg} / \mathrm{d} \text { ), 1-week stabilization, } \\
\text { then } 26 \text {-week evaluation. If seizures, can dose escalate to Keppra } 2000 \mathrm{mg} / \mathrm{d} \text {, then } 3000 \mathrm{mg} / \mathrm{d} \text {; Tegretol CR } \\
800 \mathrm{mg} / \mathrm{d} \text {, then } 1200 \mathrm{mg} / \mathrm{d} \text {. }\end{array}$ \\
\hline Outcomes & $\begin{array}{l}\text { Primary }-6 \text { month seizure freedom; secondary }-1 \text { year seizure freedom rates, } 6 \text {-month and 1-year seizure } \\
\text { freedom rates by dose level, adverse events. }\end{array}$ \\
\hline Randomization & Adequate (block randomization, central 1:1) \\
\hline Allocation Concealment & Adequate (identical encapsulated, tasting placebo and treatment) \\
\hline Blinding & Double-blind (patients, outcome assessors) \\
\hline
\end{tabular}

\section{Characteristics of Study for Seizure Prophylaxis}

\begin{tabular}{|ll|} 
Study & Szaflarski $2009^{16}$ \\
\hline Methods & $\begin{array}{l}\text { Single center, randomized, single-blinded comparative trial of IV levetiracetam to IV phenytoin for seizure } \\
\text { prevention in severe traumatic brain injury or traumatic subarachnoid hemorrhage. }\end{array}$ \\
\hline Participants, Interventions & $\begin{array}{l}\text { 52 patients randomized (34 to Keppra, 18 to Dilantin), each treated for 7 days, with continuous EEG } \\
\text { monitoring. Those included: traumatic brain injury or subarachnoid hemorrhage; with GCS 3-8. }\end{array}$ \\
\hline Outcomes & $\begin{array}{l}\text { Primary - Disability Rating Scale score, Glasgow Outcomes Scales score at 6 months; secondary - seizure } \\
\text { occurrence at 1 week, 6 months }\end{array}$ \\
\hline Randomization & Likely done \\
\hline Allocation Concealment & Unclear \\
\hline Blinding & Single (patient) blind
\end{tabular}

